\title{
Comprehension of the Social Crisis from the Sense of Urgency
}

\author{
Wenli Huang \\ Division of Social Science \\ Shanghai University \\ Shanghai, China 200444
}

\begin{abstract}
The sense of urgency has profound philosophical and practical significance. We understand the social crisis from the perspective of the sense of urgency to prevent it from happening. For the social crisis, we should have a deep sense of urgency and always keep a clear head. The transformation of the sense of urgency into the will of practice is the inevitable result of Marxist understanding of the theory of practical will. The lack of the subjectivity of the people is the internal cause of the social crisis. Strengthening the people's subjectivity is an effective way to overcome social crises.
\end{abstract}

Keywords-social crisis; the sense of urgency; the subjectivity of the people

\section{INTRODUCTION}

The sense of urgency is a reflection of the existence of society that often manifested as sorrow and emotion towards self, life, the country, and society. For the current social crisis in the real world, we should have a certain sense of urgency. On the basis of rethinking the awareness of the social crisis, we will strengthen the subjectivity of the people, strive to overcome the social crisis, and achieve orderly and benign development of society.

\section{The PHILOSOPHICAL CONNOTATION AND PRACTICAL SIGNIFICANCE OF THE SENSE OF URGENCY}

In the long history of human history, the sense of urgency has a long history. Worry has general implications such as anxiety, worry, and sorrow. The so-called suffering refers to hidden dangers, disasters, and sufferings. [1] The sense of urgency is a sense of hardship and suffering. There is a fundamental difference between the sense of urgency and the pessimism or pessimism. Pessimism is a complete desperation of life. "Eating even that life is not as good as death, trying to transcend reality to solve the problem of disengagement and salvation." [2] The sense of urgency is different. It is the subjective consciousness of individuals, nations or countries after rational thinking about self and social reality. It is a positive and enterprising spirit with profound philosophical connotation and practical significance.

\section{A. The Philosophical Connotation of the Sense of Urgency}

Within a certain scope, an appropriate sense of urgency can play an important role in the development of things and play a positive role in a certain sense. The sense of urgency has rich philosophical connotations. It is a rational speculation and thinking of people facing the development of future things. It is a dialectical negation and a kind of philosophical wisdom.

First, the sense of urgency is a rational speculation and thinking of people facing the development of things. Reason is relative to irrationality such as instinct, emotion and will, and it is an essential power and subjective ability unique to human beings. In the Concise Britannica Encyclopedia, the definition of reason is: "It refers to people's ability and activities to understand the essence of things and obtain objective truths through logical reasoning." [3] From this definition, we can know two things. First, the essence of reason lies in "logical reasoning." If there is no logical reasoning, people have no reason, and reason is something unique to human beings, and it is one of the main characteristics that distinguishes people from animals. Second, people can only understand the objective world through the laws of science and logic, grasp the essential features of things, and obtain objective truths.

One of the important characteristics of the sense of urgency is that it has a rational ability to speculate. People speculate about what hasn't happened yet and what they need to know about the world. Of course, speculation is sometimes correct and sometimes wrong. People using reason and making speculation on the basis of scientific logic will be the correct speculation. If this sense of urgency is judged on the basis of scientific logic, it will be very different from pessimism. Then it will be the correct speculation, that is, a rational thinking.

Second, the sense of urgency is a dialectical negation. A sense of urgency is a way for people to know the world and a character that finds potential problems in affirmation. Hegel advocated negation and said in the "Principles of Legal Philosophy": "If we only stay on certain things, that is to say, if we hang on to purity and goodness - that is, it is goodness at its roots, then, it is a rational emptiness rule." [4] The profoundness of the sense of urgency lies in the denial of this dialectic. This dialectical negation reveals the inherent negation of things on the basis of affirmation, thus better grasping the contradictory movement of the development of things.

The sense of urgency is a dialectical unity of knowing and resolving worry. Knowing worry is to be prepared for danger in times of peace and resolving worry is to make great efforts. It is the manifestation of this negative dialectical thinking and the main feature of the sense of urgency. The sense of urgency 
is the dialectical unity of preparing for danger in times of peace and making great efforts. Therefore, in the case of social stability and benign operation, we should also have a sense of urgency, and we must be alert and negated in the existing bad state, so as to prevent it from happening.

Third, the sense of urgency is a kind of philosophical wisdom. In the practice of human society, the development of things is often not smooth sailing. Most of them have to undergo twists and turns. People implement specific behaviors under the guidance of the sense of urgency, prevent minor mistakes, actively develop, eliminate hidden dangers, and work hard. The sense of urgency is not only a complex inner feeling of human beings, but also an ability to deal with problems.

\section{B. The Practical Significance of the Sense of Urgency}

The sense of urgency is not only the driving force for personal potential and self-realization, but also the catalyst for social change and social innovation. It is also the inexhaustible motive force for the country to prosper. Any country that is not smooth in its development process will face certain difficulties. No matter how the times change, what will last forever is that the sense of urgency is the essence of the national spirit and national culture. The sense of urgency is usually a rational consciousness of a country or nation for potential crises and conflicts at a certain stage of development.

\section{UNDERSTANDING THE SOCIAL CRISIS FROM THE PERSPECTIVE OF THE SENSE OF URGENCY}

To understand the social crisis from the perspective of the sense of urgency, the first is to show that there has not been a serious crisis, but a trend toward crisis, but this trend is enough to cause our worries. Second, the use of crisis awareness, but the sense of urgency, in addition to the first point, but also because of the sense of crisis contains crisis awareness. Crisis awareness is actually part of the sense of urgency. Treating the social crisis from the perspective of the sense of urgency, the theoretical horizon will be broader, and provide theoretical support for further finding ways to resolve the social crisis.

\section{A. Understanding of Crisis and Social Crisis}

From the point of view of the sense of urgency, the understanding of the crisis has two meanings: the first is the danger and the disaster is about to come, indicating that things are gradually dying. This is its negative side. The second understanding is that the crisis also means turning. Understand the crisis as a key turning point in the development of things, a decisive moment. At this point, at this moment, the development of things must move to one end or the opposite end, breaking the original state of things. After such a moment, things will become stronger and more mature.

With regard to the concept of social crisis, the definition of scholars in the East and West is very different. From the perspective of Marxist philosophy, we define the social crisis. The social crisis is "due to certain natural or social factors, determined by the law of basic contradictions in society and its operational mechanism. it is serious imbalance even disintegration of cyclical social structure of that through violent outbreaks and ultimately recovery through violent and periodic , and the deviation from the normal orbit during social development." [5] From the perspective of the sense of urgency, the worry's subject and content of social crisis is social rather than individual, so it is not the individual's sense of urgency, but the sense of urgency of the society. "A strong sense of urgency for a nation and society is an important indicator of whether the society is conducting self-criticism." [6]

\section{B. The Root Causes of Social Crisis}

The intensification of basic social contradictions is the root cause of social crises. When these basic social contradictions accumulate to a certain extent, a crisis will arise. From the perspective of the sense of urgency, the social crisis reflects to some extent some of the problems that arise in the process of social development and the complex mentality that people do not agree with in terms of social systems and social management. If a society's management, systems, etc. can be recognized by individuals, there will be no social crisis. But the root cause of disapproval is due to the lack of the subjectivity of people, which is the main internal cause of the social crisis. The value and status of the subject are expressed through the interests of the subject, and the subject without interest is abstract. The subjectivity of the people is linked to the interests of the people. Since the fundamental interests of the people are not fully reflected, the people's dominant position cannot play its due role, thus creating a trend of intensifying social basic contradictions. When this trend is accumulated to a certain extent, a social crisis will arise.

The squeezing and influence of pluralistic social values on social core values is the main external cause of social crisis. Due to the influence of globalization, the interaction between the pluralistic social values coexisting in society will affect the leading position of social core values to a certain extent, and interfere with the individual's recognition of the core values of the society, thus creating individual intellectual confusion and then causing conflicts in individual actions.

Internal and external factors are a pair of philosophical categories that indicate the conditions for the development of things. The development of things is often the result of the interaction of internal and external factors. Internal factors are the basis for the development of things, external factors are the conditions for the development of things, and external factors work through internal factors. For the social crisis, starting from the internal cause and the self, attaching great importance to the lack of the subjectivity of the people is an effective way to overcome the social crisis.

\section{StRIVE TO OVERCOME THE SOCIAL CRISIS IS THE INEVITABLE TREND OF RETHINKING ON THE SENSE OF URGENCY}

Rethinking is the intrinsic nature of human reason and the objective need of real development. "Rethinking takes the content of thought as its content, and strives to thought think of itself as an thought." [7] Reflection can make thoughts more profoundly grasp the reality from the content of the object's own movement. As a conscious form of theoretical thinking, one of philosophy's main functions is rethinking. This kind of thinking characteristic of rethinking requires us to reach a deep 
understanding of the social crisis problem in the study of the problem of urgency.

\section{A. Maintaining the Sense of Urgency of the Social Crisis at All Times}

History shows that the state is prosperous when it comes to the sense of urgency as an important part of ruling. Anyone who puts the sense of urgency behind him will be frustrated. Therefore, we must always maintain a sense of urgency. Our purpose of urgency is to prevent further spread of social crises. The sense of urgency of the social crisis profoundly reflects the basic social contradictions embodied or implied in the social reality that is the basis of this sense of urgency. If these basic social contradictions are not resolved in a timely and effective manner, they will be like a sword of Damocles hanging over our heads, threatening and hindering the process of social development.

\section{B. Paying Attention to the Transformation of the Sense of Urgency into the Practice Will}

In the process of resolving social crises, the transformation of the sense of urgency into the practice will is a crucial step. With the sense of urgency about the social crisis, we can prepare before the difficulties arise, but in order to finally resolve the social crisis, we must transform the sense of urgency into the practical will.

The Marxist theory of practical consciousness is produced in the criticism and debate of various non-Marxist wills. According to Marxist practice theory, material practice is the foundation of human will and the fundamental driving force for the development of will. The will of man is inseparable from practice, and all problems of will can only be solved in material practice. Understanding the will from the material practice also emphasizes the action of the will. Material practice without will can only be an abstract practice. Marxist theory of practical consciousness provides a reasonable basis for the correct understanding and interpretation of the relationship between human will and practice.

The sense of urgency, as a rational speculation and thinking, always implies the "should" formed on the basis of the needs of the subject. However, the objective world does not automatically meet the needs of people. "The effort of the will is to make this world so."[8] The will of the people always strives to pursue a more reasonable society and a better world. Pursuing the unity of truth and value is the inherent nature of human will. Therefore, the transformation of the sense of urgency into the practice will becomes a necessity, and it should be the same for the sense of urgency of the social crisis.

\section{Strengthening the Subjectivity of the People Is an Effective Way to Overcome the Social Crisis}

The lack of the subjectivity of the people is the internal cause of the social crisis. In this regard, we should strengthen the people's subjectivity and start from ourselves to find ways to resolve the social crisis. According to historical materialism, the masses of the people are the creators of history and the true subjects of social history. The main status of the people is linked to the interests of the people.
In order to enhance the people's subjectivity, first it must reflect people's interests. The lack of people's interests will inevitably lead to the lack of people's subjectivity. Under the strong push of the market economy, people are no longer afraid to discuss interests. The market has increasingly become the link and bridge between people, and economic interests have become the yardstick of social life. Among them, material interests become an important part of economic interests, so that people often use material interests to refer to economic interests. From being afraid to talk about material interests to focusing on material interests, changes in interest consciousness have provided greater impetus to people's social activities.

Secondly, it highlights the subjectivity of the people in anti-corruption. Corruption is one of the biggest concerns in China. The issue of corruption has greatly damaged the interests of the people and is the main reason for the lack of the subjectivity of the people. The people are the true masters of society, and this is the core of the subjectivity of the people. The subjectivity of the people must always be reflected through the interests of the people. However, in reality, some officials despise the relevant provisions of the Constitution and the Party Constitution, and in order to pursue their own selfinterest, they become the "master" of society from the "public servant" of society. Their corrupt actions of pursuing private interests have greatly damaged the interests of the people, restrained the exertion of the main role of the people, and intensified the basic contradictions of society.

The issue of anti-corruption is related to the credibility of the country and to the survival of the country. Adhere to the people's subjective thinking, highlight the people's subjectivity, and make the subjectivity of the people become an important concept of the ruling party. We must truly proceed from the interests of the people, increase anti-corruption efforts, and establish an effective anti-corruption mechanism. Under the premise that the interests of the people are guaranteed, the people will have the enthusiasm and motivation to participate in social production, social management and social services, so as to finally overcome the urgency of the social crisis.

\section{CONCLUSION}

In the process of social development, we must not only maintain the sense of urgency of the social crisis, but also further transform the sense of urgency into reality through the practice of will. Only by strengthening the people's subjectivity and highlighting the people's subjectivity in anticorruption can we overcome the social crisis, turn the crisis into a turning point, make people's lives happy, society stable and harmonious, and the country prosperous and strong.

\section{REFERENCES}

[1] Mou Yongsheng, Research on the sense of urgency of Fan Zhongyan [M], Nanjing University Press, 2014, p. 25.

[2] Philosophy Dictionary [Z], Shanghai: Shanghai Lexicographical Publishing House, 2001 edition, p. 58.

[3] Concise Encyclopedia of Britannica, Volume 5 [Z], Beijing: Encyclopedia of China Publishing House, 1986 edition, p. 239. 
[4] [German] Hegel, Philosophy of Right [M], translated by Fan Yang, Zhang Qitai, Beijing Commercial Press, 1981, p. 145

[5] Zhao Jihe, Chen Xiao: Journal of Yangtze Normal University [J], No.6, 2017

[6] Chen Xinhan, Self-evaluation [M], Shanghai: Shanghai People's Publishing House, 2011 edition, p. 437.

[7] [German] Hegel, The Logic [M], translated by He Lin, Beijing: The Commercial Press, 1980 edition, p. 39.

[8] [German] Hegel, The Logic [M], translated by He Lin, Beijing: The Commercial Press, 1980 edition, p. 420. 